\title{
Effects of dietary physically effective neutral detergent fiber content on the feeding behavior, digestibility, and growth of 8- to 10-month-old Holstein replacement heifers
}

\author{
H. R. Wang, ${ }^{, 1}$ Q. Chen, ${ }^{\star}$ L. M. Chen, ${ }^{*}$ R. F. Ge, ${ }^{*}$ M. Z. Wang, ${ }^{*}$ L. H. Yu, ${ }^{*}$ and J. Zhang† \\ ${ }^{*}$ College of Animal Science and Technology, Yangzhou University, Yangzhou, 225009, China \\ †The Experimental Dairy Farm, Yangzhou University, Yangzhou 225009, China
}

\begin{abstract}
The objective of this study was to evaluate the effects of dietary physically effective neutral detergent fiber (peNDF) content on the feeding behavior, digestion, ruminal fermentation parameters, and growth of 8- to 10-mo-old dairy heifers and to predict the adequacy of dietary fiber in growing dairy heifers. Twenty-four Holstein dairy heifers $(245 \pm 10.8 \mathrm{~d}$ of age, $305.6 \pm 8.5 \mathrm{~kg}$ initial live weight) were randomly divided into 4 treatments with 6 replicates as a completely randomized design. During the $60-\mathrm{d}$ period with a $10-\mathrm{d}$ adaptation, heifers were offered 1 of 4 diets, which were chemically identical but included different peNDF $_{8.0}$ (particle size is $>8 \mathrm{~mm}$ and $<19 \mathrm{~mm}$ ) content (\% DM): 10.8, 13.5, 18.0 , or $19.8 \%$, which was achieved by chopping forage into different lengths (fine $=1 \mathrm{~cm}$, short $=3 \mathrm{~cm}$, medium $=5 \mathrm{~cm}$, and long $=7 \mathrm{~cm}$ ). The concentrate and silage were mixed and fed restrictedly and exclusive of forage (Chinese ryegrass hay) were offered ad libitum. The body weight and frame size of the heifers were measured every $15 \mathrm{~d}$ during the experimental period. Samples of the rumen content $(2 \mathrm{~h}$ after the morning feeding) were taken for $\mathrm{pH}$, ammonia, and volatile fatty acid determination. The dry matter intake and average daily gain of the heifers were not significantly affected by $\mathrm{peNDF}_{8.0}$ content. The body frame size (including withers height, body length, and heart girth) of the heifers was not increased significantly by enhanced $\operatorname{peNDF}_{8.0}$ content. Ruminal $\mathrm{pH}$ and ammonia concentration were both increased with increasing dietary peNDF $_{8.0}$ content. The ruminal total volatile fatty acid concentration and percentage of acetate and butyrate profiles were not significantly affected by dietary $\mathrm{peNDF}_{8.0}$ content. However, the enhanced peNDF ${ }_{8.0}$ content led to a decrease in the propionate percentage. The ratio of acetate to propionate in the $13.5 \%$ treatment was highest among the treatments. Increasing the
\end{abstract}

Received January 20, 2016.

Accepted October 28, 2016.

${ }^{1}$ Corresponding author: hrwang@yzu.edu.cn particle size and dietary peNDF ${ }_{8.0}$ content resulted in increased eating and chewing time but had no effect on rumination time. Heifer total eating and chewing time and eating and chewing time per kilogram of dry matter intake were increased with increasing dietary peNDF $_{8.0}$ content. The apparent digestibility of acid detergent fiber and crude protein was improved with an increasing content of dietary peNDF ${ }_{8.0}$. The results suggest that an optimal or advisable dietary particle size and peNDF$_{8.0}$ content improves chewing activity, rumen fluid $\mathrm{pH}$, and ruminal fermentation. The data based on feeding behavioral and growth responses of heifers as well as rumen fermentation and digestion by improving total eating and chewing time indicate that $18.0 \%$ dietary peNDF ${ }_{8.0}$ content is the most suitable for 8- to 10-mo-old Holstein heifers.

Key words: physically effective neutral detergent fiber, feeding behavior, body growth, Holstein replacement heifer

\section{INTRODUCTION}

Heifer herd feeding and management are expensive and require extensive labor, often accounting for approximately 15 to $20 \%$ of total farm expenses (Heinrichs, 1993; Hoffman, 1997). The ability to develop strategies for raising dairy heifers efficiently is important for dairy farmers to increase profitability. Efficient utilization of feeds by dairy heifers can help to minimize rearing costs. Traditionally, heifers are often fed high-forage diets, which are inefficiently digested due to high levels of lower digestibility forage in heifer rations (Zanton and Heinrichs, 2007). Determination of the adequate amounts of dietary fiber is essential to maintaining a highly efficient rumen metabolism, the ultimate goal in heifer rearing and is a key concern in dairy cattle nutrition. Reducing the age of onset of puberty, early breeding, and thereby reducing the age at first calving are alternative ways to minimize expenses when rearing heifers. To achieve this, high concentrate diets composed of high energy and high protein are being fed frequently to accelerate growth rates of calves and 
heifers. Consequently, various reports have shown that rapid rearing by feeding high-concentrate diets not only reduces the age of sexual maturity but also decreases the time period it takes to reach the age of first calving (Gardner et al., 1977; Hoffman et al., 1996, 2007). However, high energy diets may cause undesirable fat deposition, thereby affecting mammary development and future milk yield potential (Sejrsen et al., 1982; Peri et al., 1993; Brown et al., 2005). Therefore, limit feeding has drawn attention in recent years because it offers great potential to reduce the costs associated with raising replacement dairy heifers. In addition, feeding a nutrient-dense ration in a limited amount has also the potential to reduce feed costs and nutrient or fecal excretion and to improve feed efficiency (Hoffman et al., 2007; Lascano et al., 2009; Greter et al., 2013). In fact, optimal utilization of rations by heifers is influenced by the chemical composition and physical characteristics of their rations. Carbohydrates often constitute $70 \%$ or more of the DM in dairy rations and are the major precursors of energy for ruminants. Both the amount and effectiveness of dietary fiber can affect feeding behavior, ruminal fermentation, and animal metabolism. To assess the adequacy of dietary fiber in dairy cattle, the concept of physically effective neutral detergent fiber (peNDF; Mertens, 1997) has received increasing attention because it amalgamates information on both chemical fiber content and physical characteristics (primarily particle size) of the feedstuffs. The peNDF of a diet is the product of its NDF concentration and its physical effectiveness factor (pef). In dairy cattle production, it is necessary to quantify the peNDF value in heifer diets to maintain the rumen function and growth and to achieve the optimal target BW. Hence, the peNDF in dairy cows has been intensively investigated recently, although the NRC (2001) does not recommend peNDF for any category of dairy heifers. Zebeli et al. (2008) developed practical models to assess and predict the adequacy of dietary fiber, and the method was used to evaluate the responses of ruminal $\mathrm{pH}$ and production performance to different variables including physical, chemical, and starch-degrading characteristics in the diet of high-yielding dairy cows. Furthermore, comprehensive meta-analyses about both peNDF ${ }_{8.0}$ and peNDF $_{1.18}$ recommendations for dairy cows have been performed during the last decade (Zebeli et al., 2008, 2010, 2012). However, limited information is available documenting the influence of peNDF on heifers, and the optimal concentration of peNDF in dairy heifer diets is still uncertain. Therefore, finding an optimal balance of peNDF content in the diets of dairy heifers is critical to achieve the rearing targets for body size, optimal digestion, nutrient utilization, and improved productivity. We hypothesized that optimal peNDF content in diets would benefit to improve feed digestion and efficiency, ruminal fermentation, and body growth of heifers. Thus, the objective of this study was to determine the optimal dietary peNDF for growing replacement heifers.

\section{MATERIALS AND METHODS}

\section{Animals and Feeding}

Twenty-four Holstein heifer calves with similar genetic merit, initial age $(245 \pm 10.8 \mathrm{~d})$, and BW (305.6 $\pm 8.5 \mathrm{~kg}$ ) were randomly assigned to 4 treatments with 6 replicates. A completely randomized design was applied to this trial. Heifers were individually housed and fed in a tie-stall barn during the 4 treatments, and each animal was provided with an own feed bunk. Water was available ad libitum to the heifers through a water bowl in each stall. The experiment was conducted between May and August of 2013 at the Experimental Dairy Farm of Yangzhou University (Yangzhou, China), and the use of heifers in this study was approved by the Animal Care and Ethical Committee of Yangzhou University (no. 201206118).

The heifers were given a $10-d$ adaptation period before exposure to the experimental treatment; the experiment was conducted for $60 \mathrm{~d}$. Feeding behavior was monitored continuously using 4 time-lapse video cameras (Panasonic WV-BP330, Osaka, Japan) installed on the outside of the pen following the method described by Kitts et al. (2011). Animal behaviors, including eating, chewing, and ruminating activity, were recorded as images. The vivid image signal was transmitted to a control computer. The number of jaw movements were summed each minute and stored for subsequent analysis. All other jaw movements were considered to be associated with licking, drinking, and grooming and were not included in the eating or ruminating categories. The amount of time spent feeding during the experimental period was recorded for 120 $\mathrm{h}$ for individual heifers using an instantaneous scan at each barn. Feeding, chewing activity, and rumination time were measured at 1-min intervals and recorded. For each scan, feeding was defined as when a heifer had her head completely past the feeding rail and over the feed. Total time spent eating, ruminating, and chewing (eating + ruminating) was based on the duration of each chewing activity. Chewing efficiencies were calculated by dividing voluntary DMI by the respective eating, rumination, or chewing time.

\section{Diets and Treatments}

Heifers were fed twice daily (at 0800 and $1600 \mathrm{~h}$ ) with a ration that was formulated to meet the nutrient 
requirements for a Holstein heifer growing at $0.9 \mathrm{~kg} / \mathrm{d}$ (NRC, 2001), and the concentrate and silage mixed and fed strictly and exclusive of forage (Chinese ryegrass hay) were offered ad libitum as shown in Table 1 . The rations were chemically identical but included different peNDF concentrations (DM basis) achieved by chopping Chinese wild ryegrass hay into different lengths (i.e., $10.8,13.5,18.0$, and $19.8 \%$ peNDF $_{8.0}$ ). Forage (Chinese wild ryegrass hay) was chopped into lengths of $1 \mathrm{~cm}$ (fine), $3 \mathrm{~cm}$ (short), $5 \mathrm{~cm}$ (medium), and $7 \mathrm{~cm}$ (long) using a chaff cutter (model 40B, Xingda Machine Com. Ltd., Zhengzhou, China). Corn silage (containing $34.3 \% \mathrm{DM}, 40.5 \% \mathrm{NDF}, 24.6 \% \mathrm{ADF}$, and $7.1 \% \mathrm{CP}$ on a DM basis) was prepared at the same length $(2.5$ $\mathrm{cm}$ ) approximately in different treatments. Once daily, the appropriate amount of total ration was manually weighed out and dietary components were mixed for each heifer. The total amount of feed offered to each heifer was adjusted weekly, according to total heifer BW. Grab samples of the mixed ration were taken and prepared based the percentage of forage, corn silage, and concentrate intakes in Table 1 and to measured peNDF content using a Penn State Particle Separator (Anscitech Company, Wuhan, China; Kononoff et al., 2003a). The separator consisted of 3 sieves $(1.18,8$, and $19 \mathrm{~mm}$ ) that could separate the samples into 4 fractions based on particle size. For the pef, the proportion of particles larger than $8 \mathrm{~mm}$ and less than $19 \mathrm{~mm}$ was considered to be pef $_{8.0}$ as described in Lammers et al. (1996), and the proportion of particles larger than 1.18 $\mathrm{mm}$ and less than $8 \mathrm{~mm}$ was considered to be pef $_{1.18}$ as described in Kononoff et al. (2003a). The peNDF ${ }_{8.0}$ and $\mathrm{peNDF}_{1.18}$ contents of the ration were calculated by multiplying the NDF percentage of the mixed ration by pef ${ }_{8.0}$ and pef $_{1.18}$, respectively, as shown in Table 2 .

The BW, withers height, body length, and heart girth of heifers were measured before the morning feeding from the initial day to d 15, 30, 45, and 60 during the experimental period. Individual feed intake $(\mathrm{kg}$ of $\mathrm{DM} / \mathrm{d}$ ) was recorded daily throughout the experiment. The actual intake of each individual fraction was calculated as the difference between the DM amount of each fraction in the offered feed and that in the refused feed measured the next morning. Representative grab samples of the mixed ration inclusive of forage, corn silage, and the mixed concentrate intakes were collected according to the percentage of total ration of Table 1 for particle size separation at the time of feed delivery twice weekly on $\mathrm{d} 7$ of each treatment period. Samples of the dietary components were also taken for DM and chemical analysis twice during each of the recording weeks. Fecal grab samples were collected 3 times daily at 0800,1200 , and $1800 \mathrm{~h}$ from d 20 to 24 and from d 50 to 54 of the experimental period, the fecal samples were pooled by combining approximately $100 \mathrm{~g}$ of feces from each time point. All samples were immediately frozen at $-20^{\circ} \mathrm{C}$ until they were analyzed. Feed samples were pooled for each animal and analyzed for DM, CP, $\mathrm{Ca}$, and P (AOAC International, 1995). The NDF and ADF were analyzed by an Ankom Fiber Analyzer (Ankom Technology, Fairport, NY; Van Soest et al., 1991).

Total-tract digestibility of $\mathrm{DM}, \mathrm{OM}, \mathrm{CP}, \mathrm{ADF}$, and NDF was determined on d 20 to 24 of each period (AOAC International, 1995). Apparent nutrient digestibility in heifers was measured according to method of $4 \mathrm{~N} \mathrm{HCl}$ insoluble ash (Lee and Hristov, 2013). Ruminal contents were sampled $2 \mathrm{~h}$ after the morning feeding by an esophageal tube vacuum pump sampling device (Anscitech Company, Wuhan, China) on the 15, 30, 45, and $60 \mathrm{~d}$ of the experimental period. Approximately $150 \mathrm{~mL}$ of rumen digesta was sampled after removing saliva from the top of the sampling bottle and then filtered through 4-layer cheesecloth to obtain the strained ruminal fluid (SRF). The $\mathrm{pH}$ in the SRF was measured immediately after collection using a handheld $\mathrm{pH}$ electrode (model B-4, Shanghai Chemical Company, Shanghai, China). The electrode meter was calibrated

Table 1. Ingredients, chemical composition, and nutrient content of diets fed to heifers from 8 to 10 mo of age

\begin{tabular}{|c|c|}
\hline Item & Value \\
\hline \multicolumn{2}{|l|}{ Ingredient of DM, \% } \\
\hline Chinese wild ryegrass hay & 31.0 \\
\hline Corn silage & 19.0 \\
\hline Ground corn & 22.1 \\
\hline Wheat bran & 8.5 \\
\hline Soybean meal & 9.8 \\
\hline Distillers dried grains with solubles & 7.0 \\
\hline $\mathrm{CaHPO}_{4}$ & 0.7 \\
\hline $\mathrm{NaHCO}_{3}$ & 0.2 \\
\hline Salt & 0.5 \\
\hline Limestone & 0.9 \\
\hline Premix $^{1}$ & 0.3 \\
\hline \multicolumn{2}{|l|}{ Nutrient content ${ }^{2}$} \\
\hline $\mathrm{NE}_{\mathrm{L}}, \mathrm{Mcal} / \mathrm{kg}$ & 1.6 \\
\hline $\mathrm{CP}$ & 15.2 \\
\hline NDF & 38.6 \\
\hline $\mathrm{ADF}$ & 21.9 \\
\hline NFC & 34.7 \\
\hline Starch & 23.4 \\
\hline Lignin & 4.0 \\
\hline Ether extract & 4.6 \\
\hline Ash & 6.9 \\
\hline $\mathrm{Ca}$ & 0.7 \\
\hline $\mathrm{P}$ & 0.4 \\
\hline
\end{tabular}

${ }^{1}$ The premix provided the following per kilogram of diet: $25 \mathrm{mg}$ of $\mathrm{CuSO}_{4}, 75 \mathrm{mg}$ of $\mathrm{FeSO}_{4} \cdot \mathrm{H}_{2} \mathrm{O}, 105 \mathrm{mg}$ of $\mathrm{ZnSO}_{4} \cdot \mathrm{H}_{2} \mathrm{O}, 0.0052 \mathrm{mg}$ of $\mathrm{CoCl}_{2}, 0.003 \mathrm{mg}$ of $\mathrm{Na}_{2} \mathrm{SeO}_{3}, 12,000 \mathrm{IU}$ of vitamin A, 310,000 IU of vitamin D, $25 \mathrm{mg}$ of vitamin E, $36 \mathrm{mg}$ of nicotinic acid, and 1,000 mg of choline.

${ }^{2} \mathrm{NE}_{\mathrm{L}}$ was the calculated value of feedstuffs from NRC (2001) equations: $\mathrm{NE}_{\mathrm{L}}(\mathrm{Mcal} / \mathrm{kg})=0.0245 \times \mathrm{TDN}(\%)-0.12 . \mathrm{NFC}=100-$ $(\% \mathrm{NDF}+\% \mathrm{CP}+\%$ ether extract $+\%$ ash $)$, and others were measured values. 
by a standard stock solution of PBS $(\mathrm{pH}=7.0)$. Another sample of SRF $(50 \mathrm{~mL}$ added to $5 \mathrm{~mL}$ of $50 \%$ sulfuric acid) was analyzed for ammonia concentration (AOAC International, 1995).

The $5 \mathrm{~mL}$ of $\mathrm{SRF}$ was placed into bottles containing $1 \mathrm{~mL}$ of $25 \%$ metaphosphoric acid and $1 \mathrm{~mL}$ of $0.6 \%$ 2-ethylbutyric acid and stored at approximately $-20^{\circ} \mathrm{C}$. Samples were thawed at a later date and centrifuged 3 times at $4,000 \times g$ for $30 \mathrm{~min}$ at $4^{\circ} \mathrm{C}$ to obtain a clear supernatant and were analyzed for VFA concentration using gas chromatography. The VFA were separated and quantified by a gas chromatograph (GC-17 A, Shimadzu, Tokyo, Japan), with a $15-\mathrm{m}$ Supelco Nukol silica capillary column (0.53 mm i.d., $30 \mathrm{~m}$ long, 0.5- $\mu \mathrm{m}$ film thickness; Supelco Inc., Bellefonte, PA). The temperature of the injection port was set at $220^{\circ} \mathrm{C}$, and the detector temperature was $250^{\circ} \mathrm{C}$. Temperature programing of the column: the initial temperature was $60^{\circ} \mathrm{C}$ and heated at the speed of $20^{\circ} \mathrm{C} \cdot \mathrm{min}^{-1}$ to $190^{\circ} \mathrm{C}$, where it remained for $3 \mathrm{~min}$. The injection volume was $1 \mu \mathrm{L}$.

\section{Statistical Analyses}

Data for body growth, feeding behavior, and chewing activity were subjected to ANOVA using the ANOVA with the MIXED procedure of SAS (SAS Institute Inc., 1996). For repeated measures the following model was used: $Y_{\text {in }}=\mu+T_{i}+C_{\text {in }}$, where $Y_{\text {in }}=$ an observation from nth heifer, $\mu=$ the overall means, $T_{i}=$ the fixed effect of the ith treatment, and $\mathrm{C}_{\text {in }}=$ random experimental error from the nth heifer nested within the ith treatment. Similarly, data for ruminal pH, VFA, and ammonia were analyzed by sampling time using repeated measures techniques. Data for particle distribution, peNDF of diets were averaged by period and analyzed by including particle length variables as fixed effects. Comparisons of means among 4 treatments were made using Tukey's multiple range test, and the effects of the factors were declared significant at $P \leq 0.05$. Trends were declared very significant at $P<0.01$.

\section{RESULTS AND DISCUSSION}

\section{Effects of Dietary peNDF on the DMI and Growth of Heifers}

The effects of differing peNDF ${ }_{8.0}$ content in diets on the BW, ADG, and DMI of heifers are presented in Table 3. No significant difference was found between DMI and ADG of heifers among the treatments ( $P$ $>0.05)$. The effects of different peNDF ${ }_{8.0}$ content on body frame size are presented in Table 4 . The withers height, body length, and heart girth of heifers showed no significant difference between treatments during the study period $(P>0.05)$.

Martz and Belyea (1986) observed that small particle size stimulates rapid ruminal passage of digesta and increases feed intake. Kononoff et al. (2003b) also reported that feed intake increases linearly as feed particle size decreases. In the current trial, DMI was not significantly affected by roughage particle size in the diet; this is probably a result of the lower roughage percentage (50\% DM for forage and silage) in the diet. More recently, Greter et al. (2013) reported that growing dairy heifers would choose to consume supple-

Table 2. Particle size distribution, physical effectiveness factors (pef) and physically effective neutral detergent fiber (peNDF) content of the treatment rations fed to growing dairy heifers (DM basis)

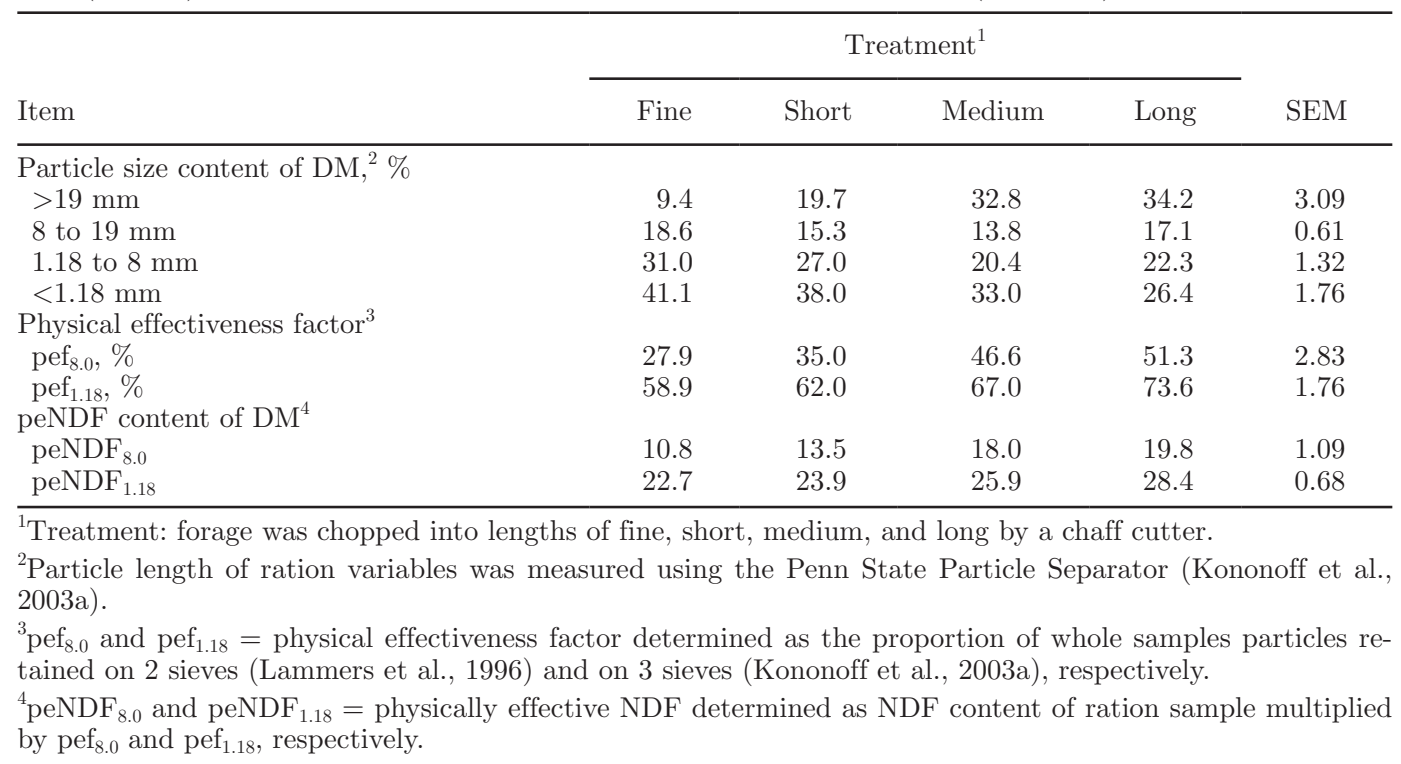


Table 3. Effects of different contents of physically effective neutral detergent fiber (peNDF) in diets on the BW, ADG and DMI of heifers

\begin{tabular}{|c|c|c|c|c|c|c|}
\hline Item & \multicolumn{4}{|c|}{ Treatment $^{1}$} & SEM & $P$-value \\
\hline Initial BW, kg & 291.8 & 311.7 & 311.9 & 307.0 & 8.53 & 0.40 \\
\hline $\mathrm{ADG}, \mathrm{kg} / \mathrm{d}$ & 0.74 & 0.75 & 0.88 & 0.97 & 0.08 & 0.19 \\
\hline DMI, kg/d & 8.81 & 8.84 & 8.80 & 8.84 & 0.47 & 1.00 \\
\hline
\end{tabular}

${ }^{1}$ Treatments: different peNDF 8.0 (particle size $>8 \mathrm{~mm}$ and $<19 \mathrm{~mm}$ ) contents of $10.8,13.5,18.0$, and $19.8 \%$ were obtained by chopping the forage into the following lengths: fine $(1 \mathrm{~cm})$, short $(3 \mathrm{~cm})$, medium $(5 \mathrm{~cm})$, and long $(7 \mathrm{~cm})$.

mentary long straw when fed nutrient-dense rations in a limited amount. When given the choice, heifers may prefer to consume longer forage, perhaps in an effort to maximize their foraging needs or to increase satiety through sufficient rumen fill. In the present study, although heifers consume similar amounts of either long or short forage with different peNDF in a limited amount ( $38.58 \% \mathrm{NDF})$, they may spend more time consuming long forage at the higher peNDF ${ }_{8.0}$.

Dairy heifer growth body size and ADG at the first calving are regarded as an important management target for the future of heifers because both can affect future milk yield potential (Sejrsen et al., 1982; Shamay et al., 2005; Lascano et al., 2009). In the present work, although no significant difference was tested, we observed the greatest ADG difference in heifers (0.23 $\mathrm{kg} / \mathrm{d}$ ) between fine and long treatments during the experimental period $(8-10 \mathrm{mo})$; this may imply that the body gain of growing heifers is insensitive to dietary fiber content. In addition, body growth was improved with increasing peNDF ${ }_{8.0}$, which corresponds to increasing DM digestibility, although the heifer's DMI did not change significantly among the treatments. However, the digestibility of DM, CP, NDF, and ADF was significantly increased compared with the control treatment $(P<0.05)$; this might be helpful for improvements in growth performance.
Considering the period costs to achieve the target $\mathrm{BW}$, the $19.9 \%$ peNDF $_{8.0}$ appears to be the most reasonable as it led to the highest ADG $(0.97 \mathrm{~kg})$ in heifers. A lower ADG may result in delayed estrus of puberty in heifers, but excessive BW reserves may also have direct negative effects on milk production (Waltner et al., 1993) and reproduction (Villa-Godoy et al., 1990). Some researchers suggested that a prepubertal ADG of approximately $0.80 \mathrm{~kg} / \mathrm{d}$ is appropriate for largebreed dairy heifers to maximize the first-lactation milk yield (Sejrsen et al., 2000; Zanton and Heinrichs, 2005). Higher ADG is associated with improved skeletal development, resulting in larger-sized heifers at parturition (Daccarett et al., 1993; Carson et al., 2002). In the present trial, BW at 10 mo for heifers was within the range of 335.1 to $364.4 \mathrm{~kg}$, which corresponded with the BW range of 380 to $400 \mathrm{~kg}$ for Holstein replacement heifers for most Chinese dairy farms proposed by Diao (2009) and with the optimum body size of replacement heifers reviewed by Hoffman (1997).

\section{Effects of peNDF Content in Diets on Feeding Behavior of Heifers}

The effects of peNDF 8.0 content in diets on the feeding behavior of heifers are presented in Table 5. Eating time per day or per dietary intake per kilogram of DM

Table 4. Effects of different physically effective neutral detergent fiber $\left(\right.$ peNDF ${ }_{8.0}$ ) content in diets on the body measurements of the frame size of heifers

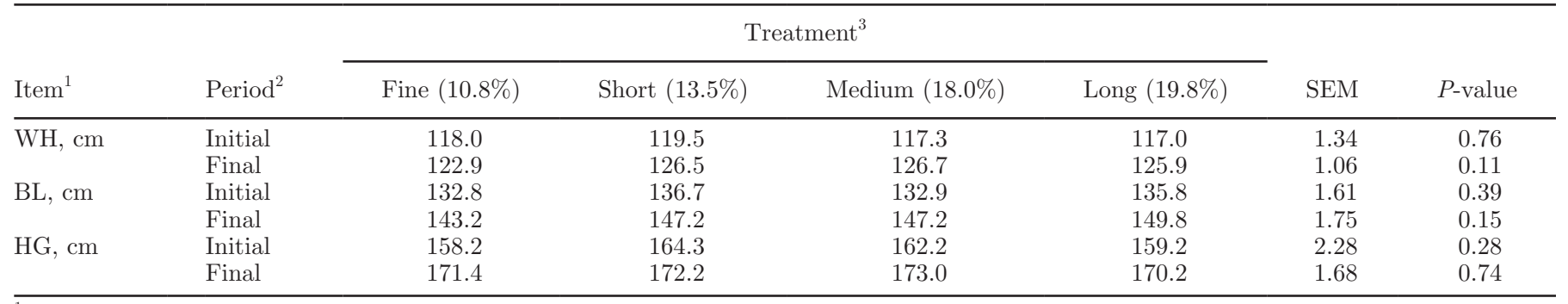

${ }^{1} \mathrm{WH}=$ withers height, measurement of height from withers to sole (or the ground when the animal was standing); BL $=$ body length, measurement of length from the shoulder blade to pin bone; $\mathrm{HG}=$ heart girth, measurement of perimeter around crops (behind the shoulder).

${ }^{2}$ The experiment lasted $60 \mathrm{~d}$.

${ }^{3}$ Treatments: different peNDF ${ }_{8.0}$ (particle size $>8 \mathrm{~mm}$ and $<19 \mathrm{~mm}$ ) contents of $10.8,13.5,18.0$, and $19.8 \%$ were obtained by chopping the forage into the following lengths: fine $(1 \mathrm{~cm})$, short $(3 \mathrm{~cm})$, medium $(5 \mathrm{~cm})$, and long $(7 \mathrm{~cm})$. 
Table 5. Effects of different contents of physically effective neutral detergent fiber $\left(\mathrm{peNDF}_{8.0}\right)$ in diets on NDF feed intake, eating time, rumination time, chewing time, and apparent nutrient digestibility in heifers

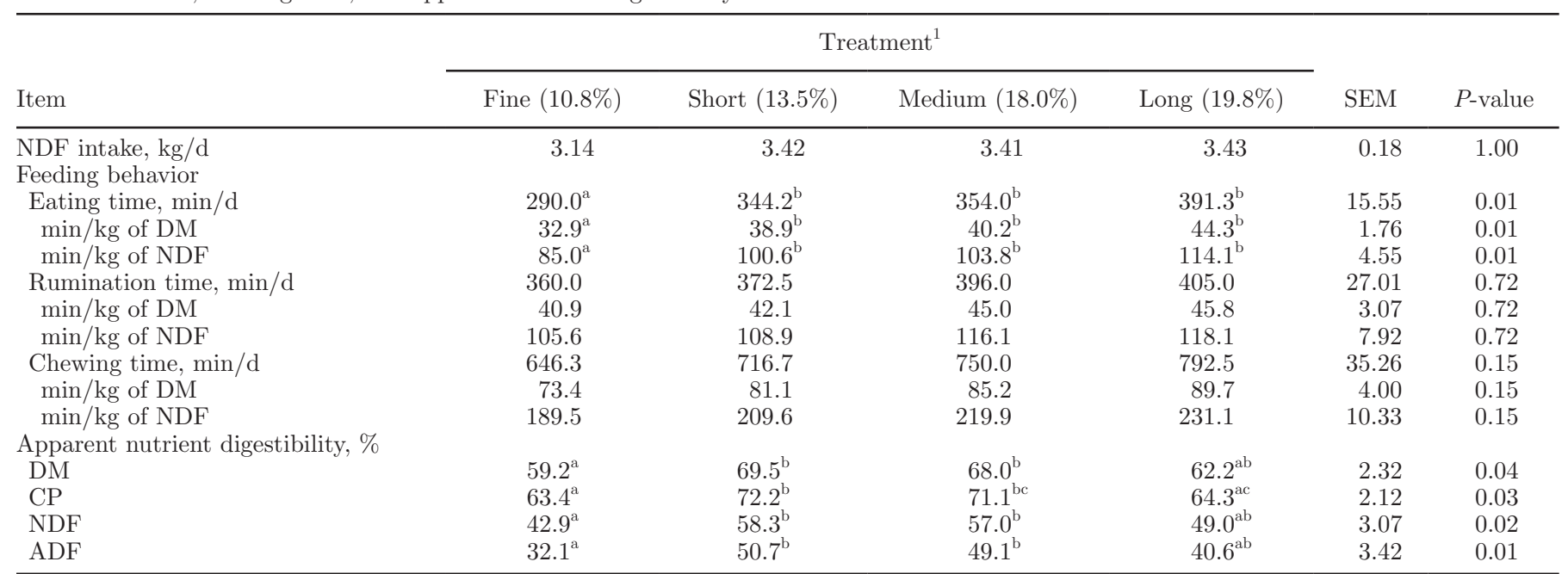

${ }^{\mathrm{a}-\mathrm{c}}$ Means within a row with different superscripts differ significantly $(P<0.05)$.

${ }^{1}$ Treatments: different peNDF 8.0 (particle size $>8 \mathrm{~mm}$ and $<19 \mathrm{~mm}$ ) contents of $10.8,13.5,18.0$, and $19.8 \%$ were obtained by chopping the forage into the following lengths: fine $(1 \mathrm{~cm})$, short $(3 \mathrm{~cm})$, medium $(5 \mathrm{~cm})$, and long $(7 \mathrm{~cm})$.

and kilogram of NDF increased with improvements to the $\operatorname{peNDF}_{8.0}$ content in the heifer diets $(P<0.05)$, where the treatment of $10.8 \%$ peNDF $_{8.0}$ was significantly shorter than that of the 13.5, 18.0, and $19.8 \%$ peNDF $_{8.0}$ treatments $(P<0.05)$. Although the values of both ruminating time and chewing time per day or per dietary intake per kilogram of DM and kilogram of NDF were prolonged with increasing peNDF $_{8.0}$ in the diets of heifers, no significant difference was found among the treatments $(P>0.05)$.

The nutritional effects of dietary PS and peNDF are complex and involve feed intake behavior, ruminal mat formation, rumination and salivation, and ruminal motility. Other effects include fermentation characteristics, digesta passage, and nutrient intake and absorption. To date, little is known about what modulates the feeding behavior of growing heifers, particularly when managed according to a limited feeding regimen. Okine and Mathison (1991) reported that the NDF content was the main factor affecting rumination time and that dietary NDF intake increases the rumination time. In the present study, increasing the particle size and dietary peNDF significantly increased the eating time $(P$ $=0.01$ ), but had no effect on chewing time and rumination time $(P>0.05)$. The peNDF is related to physical characteristics of fiber that affect chewing activity, and thus contributes to heifers spending more time chewing the long particles, so a long particle size in the diet can stimulate chewing activity. Because all treatments had a similar NDF content in this experiment, no effect was found on rumination time per dietary intake of DM, $\mathrm{NDF}$, or peNDF 8.0 . In some studies, increased chewing activity as a result of increased dietary peNDF intake has been reported (Krause et al., 2002; Yansari et al., 2004; Yang and Beauchemin, 2007a), whereas in other studies, peNDF intake was poorly related to chewing activity and ruminal $\mathrm{pH}$ as reported by Kononoff et al. (2003b) and Yang and Beauchemin (2006).

The effect of increasing dietary peNDF on chewing activity depends on how the increase in peNDF occurs. Dietary peNDF concentration can be increased both by incorporating more forage in the diet and by increasing the particle length of forages. Increased particle length affects the intake of long fiber particles, whereas increasing the forage proportion affects both the intake of fermentable $\mathrm{OM}$ and the intake of long fiber particles (Beauchemin and Yang, 2005; Yang and Beauchemin, 2007b).

\section{Effects of the Dietary Content of peNDF on Characteristics of the Ruminal Fermentation in Heifers}

The effects of different dietary peNDF ${ }_{8.0}$ content on rumen fermentation are shown in Table 6 . The ruminal $\mathrm{pH}$ and ammonia concentration of heifers were both increased significantly $(P<0.01)$ with increasing dietary peNDF $_{8.0}$ content, and the $18.0 \%$ peNDF $_{8.0}$ treatment resulted in the highest ruminal $\mathrm{pH}$ and ammonia concentration. Total VFA concentration and the proportion of acetate and butyrate in the rumen of heifers were not influenced significantly by dietary peNDF $_{8.0}$ content $(P>0.05)$, whereas the percentage of propionate was decreased significantly with increasing dietary 
Table 6. Effects of different dietary physically effective neutral detergent fiber (peNDF ${ }_{8.0}$ ) content on characteristics of the rumen fermentation in heifers

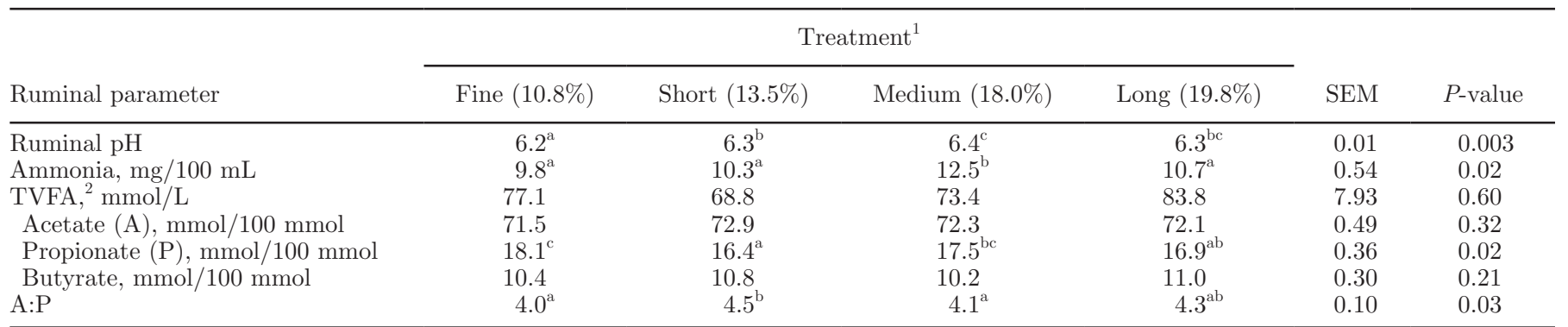

${ }^{\mathrm{a}-\mathrm{c}}$ Means within a row with different superscripts differ significantly $(P<0.05)$.

${ }^{1}$ Treatments: different peNDF ${ }_{8.0}$ (particle size $>8 \mathrm{~mm}$ and $<19 \mathrm{~mm}$ ) contents of $10.8,13.5,18.0$, and $19.8 \%$ were obtained by chopping the forage into the following lengths: fine $(1 \mathrm{~cm})$, short $(3 \mathrm{~cm})$, medium $(5 \mathrm{~cm})$, and long $(7 \mathrm{~cm})$.

${ }^{2} \mathrm{TVFA}=$ total volatile fatty acid.

$\operatorname{peNDF}_{8.0}$ content $(P=0.02)$. The ratio of acetate to propionate for the short treatment $\left(13.5 \% \operatorname{peNDF}_{8.0}\right)$ was the greatest among the treatments $(P<0.05)$.

The content of peNDF in the diet is important in maintaining a stable ruminal environment. Ruminal $\mathrm{pH}$ reflects the balance between organic acid production in the rumen and acid removal through neutralization and absorption within the rumen. Reduced forage particle size decreases the time spent chewing and causes a trend toward decreased ruminal $\mathrm{pH}$ (Woodford and Murphy, 1988). In this study, because the dietary peNDF $_{8.0}$ content was comparatively lower range from 10.8 to $19.8 \%$, the ruminal $\mathrm{pH}$ in the heifers ranged from 6.2 to 6.4 , which was far from the range of SARA (5.2 to 5.6; Owens et al., 1998). Mertens (1997) analyzed the relationship between ruminal $\mathrm{pH}$ and peNDF based on 114 observations from 26 citations and suggested that a $\mathrm{peNDF}_{8.0}$ intake of $4.4 \mathrm{~kg} / \mathrm{d}$ or a concentration of $22.3 \%$ of ration DM is needed to maintain a mean $\mathrm{pH}$ of 6.0. As particle length declines, heifers spend less time chewing, thereby decreasing the volume of saliva produced that acts to buffer ruminal contents (Grant et al., 1990). Several studies have been conducted to determine the effects of peNDF on chewing activity and ruminal $\mathrm{pH}$ in dairy cows (Krause et al., 2002; Beauchemin et al., 2003; Yang and Beauchemin, 2006). However, the responses obtained from the current literature have been somewhat inconclusive. Some studies indicated that increased chewing activity was the result of increased peNDF intake and an increased ruminal pH level (Krause et al., 2002; Beauchemin et al., 2003), whereas other research has shown that peNDF intake was poorly related to chewing activity and ruminal pH (Allen, 1997; Kononoff and Heinrichs, 2003b; Yang and Beauchemin, 2006). Adequate amounts of dietary peNDF are important for the optimization of ruminal $\mathrm{pH}$ when feeding a highly fermentable diet to dairy heifers. In the present experiment, heifers may experi- ence more severe depressions in ruminal $\mathrm{pH}$ as a result of rapidly consuming a high concentrate diet (at $>45 \%$ DM of the ration) highly composed of NFC (34.7\%). Moreover, peNDF requirements of animals depend on the fermentability of the starch source (i.e., starch type and endosperm structure). Indeed, one of the drawbacks of the peNDF concept is that it does not take into consideration the differences in ruminal fermentability of various feedstuffs. Hence, we encourage conducting another experiment on the effect of ratio of peNDF to starch on feeding behavior and growth of growing Holstein heifers. Generally, chewing activity can increase with increasing intake of peNDF without elevating ruminal $\mathrm{pH}$, particularly when diets contain highly fermentable carbohydrate sources (Kononoff et al., 2003b; Beauchemin and Yang, 2005), which can have a major effect on ruminal $\mathrm{pH}$. In the present study, the ruminal $\mathrm{pH}$ and ammonia concentration were increased significantly $(P<0.01)$ with increasing particle size and peNDF, even though the animals were offered a comparatively lower level of peNDF ${ }_{8.0}(10.8$ to $19.8 \%$ ). The increased chewing time could have also contributed to an increased buffering capacity within the rumen. More time spent on chewing can increase saliva to buffer the ruminal $\mathrm{pH}$, thereby leading to a high ruminal $\mathrm{pH}$ value. Therefore, chewing time is generally increased with increasing peNDF content, but the amount of chewing per unit intake is inconsistent because it is affected by other factors such as fermentability of the diet.

Rumen VFA concentration reflects an integrated balance of organic acid, which is affected by the production, absorption, and turnover rate in the rumen. In the current study, the total VFA had a tendency to be negatively affected by peNDF ${ }_{8.0}$, except for the long forage $(19.8 \%)$ treatment, whereas the ratio of acetate to propionate was increased with peNDF ${ }_{8.0}$ content in the diet. This decrease of VFA in the rumen fluid with in- 
creasing dietary peNDF might be attributed to the positive effect of peNDF on rumen motility. Similar to this result, Firkins et al. (2001) observed that the acetate to propionate ratio correlated positively with forage NDF and negatively with nonstructural carbohydrates in the diet of dairy cows. The fiber degradation in the rumen can produce more acetate, whereas starch degradation produces more propionic acid. However, starch content in diets was the same among treatments of this study; the cause of the higher ratio of acetate to propionate may be that the long particle size diet reduced starch digestibility, which leads to a high propionate content. In addition, the concentration of ruminal total VFA is relatively lower (70 to $80 \mathrm{mM}$ ) and the $\mathrm{pH}$ value was maintained at a higher level (above 6.2) after the 2-h feeding; this may be partially due to contamination with saliva during sampling via the esophagus.

\section{Effect of peNDF Content in Diets on Apparent Nutrient Digestibility of Heifers}

Digestibility of ADF, NDF, CP, and DM decreased $(P<0.05)$ with increasing peNDF ${ }_{8.0}$ content in the diet of heifers as demonstrated in Table 5, where the highest value was observed as $13.5 \%$ of dietary peNDF ${ }_{8.0}$. A significant difference was observed in the apparent digestibility of DM, NDF, and $\mathrm{CP}$ among the treatments $(P<0.05)$, and apparent digestibility of ADF of 13.5 and $18.0 \%$ peNDF $_{8.0}$ treatments was significantly greater $(P=0.01)$ compared with that of the $10.8 \%$ peNDF $_{8.0}$ treatment.

Several studies have shown that the effect of dietary peNDF content on NDF digestibility in dairy cattle has been inconsistent. Zebeli et al. (2006) observed that dietary peNDF and digested OM of forage in the diet correlated positively to chewing $\left(\mathrm{R}^{2}=0.23\right)$. In contrast, research conducted by Maulfair et al. (2011) showed that the larger particle size of hay in TMR decreased apparent digestibility of DM in dairy cows. In the present study, in support of our hypothesis, we found that the apparent digestibility of DM, CP, NDF, and ADF varied with dietary peNDF content; the highest digestibility was observed in the $13.5 \%$ peNDF $_{8.0}$ treatment and then decreased when the peNDF 8.0 threshold was reached. This pattern implies that feeding diets with an excess of peNDF ${ }_{8.0}$ content can lower both feed intake and digestibility accordingly. The enhanced digestibility of DM, CP, and NDF could be in accordance with the results of improving the fermentation and digestibility of diets. Additionally, the effect of peNDF in the diet depends on many other dietary (e.g., grain amount and fermentation, starch characteristics, forage degradation) and nondietary factors (e.g., sorting behavior and bulk management). It is recommended that these factors, especially starch, are subjected to further research.

\section{CONCLUSIONS}

The results of this study indicated that dietary peNDF $_{8.0}$ content had greater effects on the rumen fermentation (such as ruminal $\mathrm{pH}$ and ammonia), chewing activity (eating time and chewing time) and apparent nutrient digestibility in heifers, but no effect on DMI and body growth of heifers. Based on the results of this experiment, a content of $18.0 \%$ dietary peNDF ${ }_{8.0}$ is the most suitable for 8- to 10-mo-old Holstein heifers. Overall, a level of approximately 18 to $20 \%$ peNDF $_{8.0}$ in diet may be considered as the general optimal level of peNDF to maintain sufficient functioning of the rumen ecosystem and higher feed digestibility and to attain the target body growth in dairy replacement heifers.

\section{ACKNOWLEDGMENTS}

The authors declare that there are no known conflicts of interest associated with this publication. The authors acknowledge the funding received to conduct this study from the project funded by the National Science and Technology Support Program (12th Five-Year Plan), Ministry of Science and Technology of China (grant no. 2012BAD12B02-2), the National Natural Science Foundation of China (no. 31572429), and by the Priority Academic Program Development of Jiangsu Higher Education Institutions (PAPD). The authors express their gratitude to the staff of the Experimental Dairy Farm of Yangzhou University for providing the heifers used in this experiment and their contribution to this study.

\section{REFERENCES}

Allen, M. S. 1997. Relationship between fermentation acid production in the rumen and the requirement for physically effective fiber. J. Dairy Sci. 80:1447-1462.

AOAC International. 1995. Official Methods of Analysis. 16th ed. AOAC International, Arlington, VA.

Beauchemin, K. A., and W. Z. Yang. 2005. Effects of physically effective fiber on intake, chewing activity, and ruminal acidosis for dairy cows fed diets based on corn silage. J. Dairy Sci. 88:2117-2129.

Beauchemin, K. A., W. Z. Yang, and L. M. Rode. 2003. Effects of particle size of alfalfa-based dairy cow diets on chewing activity, rumen fermentation, and milk production. J. Dairy Sci. 86:630-643.

Brown, E. G., M. J. VandeHaar, K. M. Daniels, J. S. Liesman, L. T. Chapin, J. W. Forrest, R. M. Akers, R. E. Pearson, and M. S. Weber Nielsen. 2005. Effect of increasing energy and protein intake on mammary development in heifer calves. J. Dairy Sci. 88:595-603.

Carson, A. F., L. E. R. Dawson, M. A. McCoy, D. J. Kilpatrick, and F. J. Gordon. 2002. Effects of rearing regime on body size, reproductive performance and milk production during the first lactation in high genetic merit dairy herd replacements. Anim. Sci. 74:553-565. 
Daccarett, M. G., E. J. Bortone, D. E. Isbell, J. L. Morrill, and A. M. Feyerherm. 1993. Performance of Holstein heifers fed $100 \%$ or more of National Research Council requirements. J. Dairy Sci. 76:606-614.

Diao, Q. Y. 2009. Nutrient requirements and management for replacement dairy heifers. Dairy Sci. Technol. 3:101-105. (In Chinese).

Firkins, J. L., M. L. Eastridge, N. R. St-Pierre, and S. M. Noftsger. 2001. Effects of grain variability and processing on starch utilization by lactating dairy cattle. J. Anim. Sci. 79(E. Suppl.):218-238.

Gardner, R. W., J. D. Schuh, and L. G. Vargus. 1977. Accelerated growth and early breeding of Holstein heifers. J. Dairy Sci. 60:1941-1948.

Grant, R. J., V. F. Colenbrander, and D. R. Mertens. 1990. Milk fat depression in dairy cows: Role of particle size of alfalfa hay. J. Dairy Sci. 73:1823-1833.

Greter, A. M., M. Prinsen, T. F. Duffield, B. W. McBride, T. M. Widowski, and T. J. DeVries. 2013. Growing dairy heifers prefer supplementary long straw when fed a nutrient-dense ration in a limited amount. J. Dairy Sci. 96:3950-3958.

Heinrichs, A. J. 1993. Raising dairy replacements to meet the needs of the 21st century. J. Dairy Sci. 76:3179-3187.

Hoffman, P. C. 1997. Optimum body size of Holstein replacement heifers. J. Anim. Sci. 75:836-845.

Hoffman, P. C., N. M. Brehm, S. G. Price, and A. Prill-Adams. 1996. Effect of accelerated postpubertal growth and early calving on lactation performance of primiparous Holstein heifers. J. Dairy Sci. 79:2024-2031

Hoffman, P. C., C. R. Simson, and M. Wattiaux. 2007. Limit feeding of gravid Holstein heifers: Effect on growth, manure nutrient excretion, and subsequent early lactation performance. J. Dairy Sci. 90:946-954.

Kitts, B. L., I. J. H. Duncan, B. W. McBride, and T. J. DeVries. 2011. Effect of the provision of a low-nutritive feedstuff on the behavior of dairy heifers fed a high-concentrate ration in a limited amount. J. Dairy Sci. 94:940-950.

Kononoff, P. J., A. J. Heinrichs, and D. R. Buckmaster. 2003a. Modification of Penn State forage and total mixed ration particle separator and the effects of moisture content on its measurements. J. Dairy Sci. 86:1858-1863.

Kononoff, P. J., A. J. Heinrichs, and H. A. Lehman. 2003b. The effect of corn silage particle size on eating behavior, chewing activities, and rumen fermentation in lactating dairy cows. J. Dairy Sci. 86:3343-3353.

Krause, K. M., D. K. Combs, and K. A. Beauchemin. 2002. Effects of forage particle size and grain fermentability in mid lactation cows. II. Ruminal pH and chewing activity. J. Dairy Sci. 85:1947-1957.

Lammers, B. P., D. R. Buckmaster, and A. J. Heinrichs. 1996. A simple method for the analysis of particle sizes of forage and total mixed rations. J. Dairy Sci. 79:922-928.

Lascano, G. J., G. I. Zanton, F. X. Suarez-Mena, and A. J. Heinrichs. 2009. Effect of limit feeding high- and low-concentrate diets with Saccharomyces cerevisiae on digestibility and on dairy heifer growth and first-lactation performance. J. Dairy Sci. 92:5100-5110.

Lee, C., and A. N. Hristov. 2013. Evaluation of acid-insoluble ash and indigestible neutral detergent fiber as total-tract digestibility markers in dairy cows fed corn silage-based diets. J. Dairy Sci. 96:5295-5299.

Martz, F. A., and R. L. Belyea. 1986. Role of particle size and forage quality in digestion and passage by cattle and sheep. J. Dairy Sci. 69:1996-2008.

Maulfair, D. D., M. Fustini, and A. J. Heinrichs. 2011. Effect of varying total mixed ration particle size on rumen digesta and fecal particle size and digestibility in lactating dairy cows. J. Dairy Sci. 94:3527-3536.

Mertens, D. R. 1997. Creating a system for meeting the fiber requirements of dairy cows. J. Dairy Sci. 80:1463-1481.

NRC. 2001. Nutrient Requirements of Dairy Cattle. 7th rev. ed. Natl. Acad. Sci. Washington, DC.

Okine, E. K., and G. W. Mathison. 1991. Effect of feed intake on particle distribution, passage of digesta, and extent of digestion in the gastrointestinal tract of cattle. J. Anim. Sci. 69:3435-3445.
Owens, F. N., D. S. Secrist, W. J. Hill, and D. R. Gill. 1998. Acidosis in cattle: a review. J. Anim. Sci. 76:275-286.

Peri, I., A. Gertler, I. Bruckental, and H. Barash. 1993. The effect of manipulation of energy allowance during the rearing period of heifers on hormone concentrations and milk production in first lactation cows. J. Dairy Sci. 76:742-751.

SAS Institute Inc. 1996. SAS User's Guide: Version 7 ed. SAS Institute Inc., Cary, NC.

Sejrsen, K., J. T. Huber, H. A. Tucker, and R. M. Akers. 1982. Influence of nutrition of mammary development in pre- and postpubertal heifers. J. Dairy Sci. 65:793-800.

Sejrsen, K., S. Purup, M. Vestergaard, and J. Foldager. 2000. High body weight gain and reduced bovine mammary growth: Physiological basis and implications for milk yield potential. Domest. Anim. Endocrinol. 19:93-104.

Shamay, A., D. Werner, U. Moallem, H. Barash, and I. Bruckental. 2005. Effect of nursing management and skeletal size at weaning on puberty, skeletal growth rate, and milk production during first lactation of dairy heifers. J. Dairy Sci. 88:1460-1469.

Van Soest, P. J., J. B. Robertson, and B. A. Lewis. 1991. Methods for dietary fiber, neutral detergent fiber, non-starch polysaccharides in relation to animal nutrition. J. Dairy Sci. 74:3583-3597.

Villa-Godoy, A., T. L. Hughes, R. S. Emery, E. P. Stanisiewski, and R. L. Fogwell. 1990. Influence of energy balance and body condition on estrus and estrous cycles in Holstein heifers. J. Dairy Sci. 73:2759-2765.

Waltner, S. S., J. P. McNamara, and J. K. Hillers. 1993. Relationships of body condition score to production variable in high producing Holstein dairy cattle. J. Dairy Sci. 76:3410-3419.

Woodford, S. T., and M. R. Murphy. 1988. Effect of forage physical form on chewing activity, dry matter intake, and rumen function of dairy cows in early lactation. J. Dairy Sci. 71:674-686.

Yang, W. Z., and K. A. Beauchemin. 2006. Effects of physically effective fiber on chewing activity and rumen $\mathrm{pH}$ of dairy cows fed diets based on barley silage. J. Dairy Sci. 89:217-228.

Yang, W. Z., and K. A. Beauchemin. 2007a. Altering physically effective fiber intake through forage proportion and particle length: Chewing and rumen pH. J. Dairy Sci. 90:2826-2838.

Yang, W. Z., and K. A. Beauchemin. 2007b. Altering physically effective fiber intake through forage proportion and particle length: Digestion and milk production. J. Dairy Sci. 90:3410-3421.

Yansari, A. T., R. Valizadeh, A. Naserian, D. A. Christensen, P. Yu, and F. E. Shahroodi. 2004. Effects of alfalfa particle size and specific gravity on chewing activity, digestibility, and performance of Holstein dairy cows. J. Dairy Sci. 87:3912-3924.

Zanton, G. I., and A. J. Heinrichs. 2005. Meta-analysis to assess effect of prepubertal average daily gain of Holstein heifers on firstlactation production. J. Dairy Sci. 88:3860-3867.

Zanton, G. I., and A. J. Heinrichs. 2007. The effects of controlled feeding of a high-forage or high- concentrate ration on heifer growth and first-lactation milk production. J. Dairy Sci. 90:3388-3396.

Zebeli, Q., J. R. Aschenbach, M. Tafaj, J. Boguhn, B. N. Ametaj, and W. Drochner. 2012. Role of physically effective fiber and estimation of dietary fiber adequacy in high-producing dairy cattle. J. Dairy Sci. 95:1041-1056.

Zebeli, Q., J. Dijkstra, M. Tafaj, H. Steingass, B. N. Ametaj, and W. Drochner. 2008. Modeling the adequacy of dietary fiber in dairy cows based on the responses of ruminal $\mathrm{pH}$ and milk fat production to composition of the diet. J. Dairy Sci. 91:2046-2066.

Zebeli, Q., D. Mansmannab, B. N. Ametajb, H. Steingass, and W. Drochnera. 2010. A model to optimize the requirements of lactating dairy cows for physically effective neutral detergent fibre. Arch. Anim. Nutr. 64:265-278.

Zebeli, Q., M. Tafaj, H. Steingass, B. Metzler, and W. Drochner. 2006. Effects of physically effective fiber on digestive processes and milk fat content in early lactating dairy cows fed total mixed rations. J. Dairy Sci. 89:651-668. 